\title{
"The Impact of Cognitive Creativity in Accounting among Jordanian Internal Auditors on Detecting Creative Accounting Practices, A Field Study"
}

\author{
Dr. Nofan Hamed Al-Olimat \\ Associate Professor \\ Accounting Department \\ Al Albayt University
}

\begin{abstract}
This study aimed to identify the impact of cognitive creativity in accounting among Jordanian internal auditors on detecting creative accounting practices at Jordanian public shareholding industrial companies. The study sample consisted of Internal Audit staff at each company; whereby 156 questionnaires were distributed, of which 128 were valid for analysis. The software used for processing and analyzing data was smart PLS .After data analysis, the study results showed that there is a statistically significant positive impact for cognitive creativity in accounting among Jordanian internal auditors as regards (creativity resources, creativity type and creativity supports) on detecting creative accounting practices at Jordanian public shareholding industrial companies. The key recommendations of the study included enforcing the role of oversight bodies, especially internal audit, in the sample companies wherein internal audit is a major cornerstone of internal control; developing the legislations that regulate the practice of internal auditors in order to enable them to implement audits across the elements and components of financial statements professionally and away from management pressures, and to allow them to identify and mitigate all creative accounting practices.
\end{abstract}

Keywords: Cognitive creativity, internal auditors, creative accounting practices

\section{Introduction:}

The emergence of accounting and the evolution of its branches resulted from the interaction of economic, social and legal factors which created the need for the services of accountants specialized in providing information that help in identifying the actual outcomes of an enterprise's activity during a certain period through its financial statements, thus allowing management to rationalize decision-making. Due to the failure to generate certain gains, some parties aimed to achieve certain personal goals through processing or manipulating the company's accounting information by applying sophisticated accounting methods, taking advantage of some accounting policies or legal loopholes, a procedure known as creative accounting (Jamal \&Ahmad: 2011).

As a result of the massive changes and developments to the business environment, enterprises are facing bigger challenges in achieving their targets, especially after the financial scandals that hit several large companies across the world, which were mainly caused by the weakness of internal control systems. Many researchers including Zabanya (2009) considered internal audit to be a key element of internal control in organizations in general and shareholding companies in particular. Alnsour (2009) and IIA (2004) attributed the weakness of control systems to the lack of attention and support by companies' managements to internal auditors and audit systems. Thus, the aim of this study is to identify the impact of cognitive creativity in the audit field among internal auditors in Jordan on detecting creative accounting practices.

\section{Conceptual Framework and Previous Studies:}

Creative accounting emerged when companies faced difficulties during the recession which took place in the early 1980s, when there was pressure to generate better earnings whereas such earnings were not achievable. Companies discovered that the laws tell you what not to do, but not what to do, they saw that if you cannot make earnings, you can at least look like you do (Dahmash \& Abu Zir, 2005) and (Alkhashawi \& Aldosari, 2008).

Alqutaish and Alsofi (2011) affirmed that the purpose was to manipulate financial statements to reach certain targets through merging accounting figures in order to create a satisfactory impression for the users of financial statements. Ever since, creative accounting has been the biggest challenge for the accounting practice because it is difficult to discover (Amat \& Gowthrope, 2011). 
Mohammad (2005) indicates that creative accounting uses new and unconventional methods, ways, procedures, concepts, standards and theories that can be used to interpret, analyze or resolve an accounting problem faced by management, with the purpose of presenting accounting information in the form of high quality information that can be used by beneficiaries. Such information is always sought by users, thus more value is assigned thereto.

\section{Accounting creativity and creative accounting:}

Alfadhl (2009) argues that creativity is the companion of the human life, and he who does not have a high level of knowledge cannot be creative, and that cognitive accumulation is the first step towards creativity. Cognitive creativity in accounting is an applied intellectual creativity associated with reality over the historical evolution of accounting. It is also associated with the changes to the environment and that accounting is a social science which affects society and society affects it as well.

It is defined by Al Ameri and Yaquob (2010) as an integrated system of subjective, objective and behavioral mechanisms and accumulated expertise, coupled with the ability to employ academic and practical qualifications, accounting realization and inspiration in order to generate accounting ideas. It is, then, the opposite of creative accounting.

It is generally agreed that accounting is a social science that interacts with the surrounding society and that accounting is based on the delegation theory whereby management of companies is delegated to managers who function on behalf of stakeholders and earn portions of their companies' profits. Therefore, the biggest concern for these managers is to maximize profits so they can generate more returns and income (Abdullah, 2015). This has led to the emergence of new accounting methods that take advantage of the flexibility of accounting standards through manipulating ways to identify earnings and revenues. Such methods are known as creative accounting (Tassadaq \& Malik, 2015).

There are many definitions of creative accounting in the accounting literature, mostly addressing the notion of unrealistic presentation of income and the statement of financial position, thus creating a fictitious picture of the entity's situation (AlKilani, 2008).

It was defined by Naser \& Pendlebury (1992) as the "changing of financial accounting figures from they actually are into a different outcome through manipulating or benefiting from the existing laws, and ignoring some or all of these laws". It was defined by Philips \& Regos (2010) as a process wherein accountants use their knowledge of accounting rules to manipulate the accounting figures presented in a company's accounts. It was addressed by Al-Obaidi (2008) as a set of methods applied by accountants through their past experience to show numbers in financial statements in a manner that reflects the interests of a certain group at the expense of the remaining groups. Al-Halabi (2009) affirms that creative accounting shows accounting numbers the way are preferred to be, rather than the way they should be.

Bataineh (2010) defines it as the application of certain methods to give the enterprise a better look in terms of the strength of its financial position, the volume of its earnings or its competitive edge.

Meshhen (2015) and Majeed (2013) indicated that it is the process wherein accountants use their knowledge of accounting rules to process the numbers recorded in the accounts of business enterprises. It is a comprehensive and conclusive description of the manipulation of amounts or financial presentation for internal motives.

It is defined by Breton \& Taffler (2003) as the procedures or steps used to manipulate financial figures using accounting principles' options and practices, or any procedure or step towards earnings management or income introduction.

In light of the above, the researcher concludes that creative accounting represents certain new, complicated and innovative methods through which accountants can use their knowledge of the flexibility of accounting laws to process and manipulate the numbers recorded in final accounts in order to attain the personal interests of a certain group. Therefore, accounting creativity is needed to generate accounting ideas, academic qualifications and practical expertise to enhance the actual performance of the enterprise and achieve the interests of all stakeholders in fairness without personal bias, so that the financial reports would reflect the current situation of the enterprise.

\section{Motives for using creative accounting:}

It is noted by Abu Ajileh \& Hamdan (2009), Mokalled (2010), Abdulfattah (2011) and Alzabadi (2015) that the ultimate motive for using creative accounting is to manipulate the financial statements and deceive its users for unethical purposes through illegal practices, relying on flexibility, choice between policies and alternative accounting methods. Al-Agha (2011) pointed out that the main motive is the conflict of interests between the different stakeholders in the enterprise, defending owners through creative accounting, manipulating accounting numbers to create a positive image for the economic unit, obtaining or maintaining financing. It may also take the form of intentional lowering of profits to influence share prices in the stock market, or improving the financial performance of the unit in order to attain personal gains. 


\section{Methods used in creative accounting:}

There are several ways and methods used in creative accounting. Examples are, but not limited to, the following (Keiso: 2009):

Accounting rules sometimes allow the company to choose between a number of different accounting methods. For example, in a number of countries a company is allowed to choose between de-recognizing research and development expenses or depreciating them over the period of the relevant project, so the company can select the policy which grants it the better image.

The use of some inputs in accounts related to assessment or forecasting. In some cases, when the age of an asset is assessed to calculate depreciation, such calculations are undertaken at work, thus allowing the creative accountant to err on the side of being to prudent or too optimistic in the assessment. In some other cases, an external expert may be hired to make the assessment. For example, a statistical expert may assess the future financial liability for pensions; in this case the creative accountant can manipulate the value either through the method through which a total of the assessment is calculated or through selecting a valuer who is known to take a prudent or optimistic approach as the accountant desires. Also, the timing of transactions can be manipulated by choosing a certain year for charging income or loss for any purpose required by the accountant, especially when there are significant differences between the book value and the market value or actual value.

Many of the relevant previous studies have addressed the conceptual framework of creative accounting in light of the accounting code of conduct and international accounting and auditing standards such as Ramo (2018). On the other hand, Majeed (2013) highlighted the concept of creative accounting and analyzed its factors, impacts and the challenges faced by auditors in dealing with creative accounting practices. Al-Halabi (2009) pointed out the role played by auditors in mitigating creative accounting. Al-Ameen (2015) concluded that auditors play a key role in measuring the relationship between the methods and motives of creative accounting in Syrian joint stock companies. Khalawi (2016) concluded that there is an impact for applying fair value use in light of the creative accounting practices in the Iraqi commercial banking field. Other studies concluded that accountants, auditors and users of financial statements are aware of creative accounting practices in the statement of cash flows such as Abu Tamam (2013), that financial statements are under question due to the use of creative accounting methods (2015) and that creative accounting methods are affecting the quality of accounting information in the financial reports of companies listed in the Iraqi stock exchange (AlHadi, AlHussein \& AlBaaj, 2017). In a study applied by Meshhen (2015) on a sample of financial statements of some Iraqi banks, he found that some banks used creative accounting methods and procedures in their financial statements. Hussein (2010) found that there is an impact of creative accounting methods on the decisions of investors in light of the varying market efficiency. Ismail (2014) pointed out that both the accountant and the auditor play a vital role in mitigating the effects of creative accounting on the credibility of accounting information at government-owned Iraqi banks. Other studies showed the impact of such unethical practices on the companies listed in the Algerian stock market such as Laarosi \& Qassimi (2016), also emphasizing that an effective control system at joint stock companies would combat creative accounting practices in Algerian companies as a result of the study by Al-Oday \& Sqour (2014). Also, Al-Jaarat \& Abu Khalifa (2015) proposed a model of creative accounting controls. The model consists of three types of controls to prevent companies from practicing creative accounting in their financial statements.

In his pilot study, Alghadanfari (2013) concluded that there are positive contributions for the accountant's ethical behavior in eliminating the practice of creative accounting. Al-Ameri \& Yaqoub (2010) distinguished between accounting creativity and creative accounting in order to reach financial statements that reflect the reality without any personal bias to meet the interests of all stakeholders, which can only be achieved by moving from creative accounting to accounting creativity.

Reflecting on the above, the researcher believes that many previous studies have addressed creative accounting from various perspectives but ignored one very important area except (Al-Ameri \& Yaqoub (2010)), which is identifying the impact of cognitive creativity in accounting among internal auditors in detecting creative accounting practices. It is impossible to overcome and detect creative accounting practices by internal auditors without cognitive creativity through directing creativity resources, types and reinforcers towards serving and improving the accounting practice, and overcoming difficulties that face the progression of enterprises.

Accordingly, and based on the findings of prior studies, the following three main hypotheses can be drafted:

1- There is no impact for the resources of cognitive creativity in accounting among internal auditors on mitigating creative accounting practices.

2- There is no impact for the type of cognitive creativity in accounting among internal auditors on mitigating creative accounting practices. 
3- There is no impact for the reinforcers of cognitive creativity in accounting among internal auditors on mitigating creative accounting practices.

Study Model:

Dependent variable

Independent variables

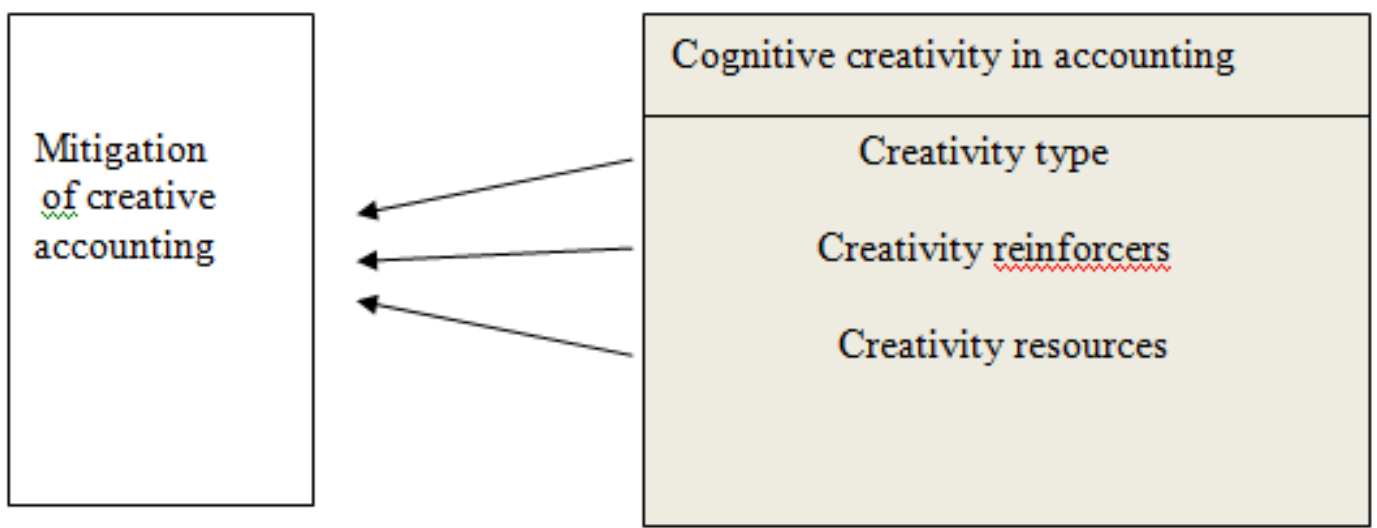

Source: Prepared by the researcher based on previous studies

\section{Study Methodology:}

\section{Study Population and Sample}

The study population consists of internal auditors at Jordanian industrial public shareholding companies ( $\mathrm{n}=78)$ in 2018 (ase.com.jo).

The study sample consists of internal audit department managers and deputy managers in each company. A total of 156 questionnaires were distributed, of which 144 were recovered. After filtering, 16 questionnaires were disqualified due to incomplete or random information provided, so the sample size was 128 respondents.

\section{Study Instrument}

The questionnaire was used as a data collection tool. It was designed and developed specifically for the purposes of this study in order to identify the impact of cognitive creativity in accounting among Jordanian internal auditors in mitigating creative accounting practices. The questionnaire was built on the basis of the study literature and the mentioned previous study. It consisted of 23 paragraphs to measure cognitive creativity in accounting (independent variable) and its dimensions (type of cognitive creativity in accounting, resources of cognitive creativity in accounting and reinforcers of cognitive creativity in accounting) which were categorized as follows:

The type of cognitive creativity in accounting was measured through the following paragraphs:

Inspiration and ability; auditor's academic and practical qualifications; auditor's skills, creative thinking and realization; auditor's academic, administrative and market needs; unexpected incidents; auditor's new knowledge; auditor's laws, regulations and instructions; availability of training and development programs; auditor's academic participation; auditor's cognitive, intellectual and technical expertise.

Resources of cognitive creativity in accounting: These are measures using the following paragraphs:

Auditor's administrative creativity; enterprise staff's internal creativity; radical creativity applied in introducing a modern accounting tool; systematic creativity applied in using new accounting systems by the auditor; auditor's individual or collective creativity; external creativity like providing consultancy services within the accounting work of the auditor; auditor's planned creativity.

Reinforcers of creativity in accounting: These are measures using the following paragraphs:

Formulation of regulations and instructions in a flexible manner that helps the auditor to innovate; providing the technical expertise and advice; increasing effective communication between the employees within the company or the unit; encouraging the attendance of seminars and scientific meetings to access the latest developments in the accounting domain; the requirements of internal control systems to mitigate creative accounting practices; the ethical commitment of the employees of the establishment; the development of an incentive system that helps generate new ideas of creativity and encourage all management practices; the company seeks to promote new values, accept and encourage change. 
The dependent variable (mitigation of creative accounting practices) was measured using the following paragraphs: The auditor makes sure that income is early recorded; the auditor makes sure that no fake (unrealistic) income is recorded; the auditor makes sure that revenues are not increased through a one-time return or non-recurring activities; the auditor makes sure that expenses of the current period are not transferred to future periods; the auditor makes sure that current revenues are not transferred to the next financial period; the auditor makes sure that no expenses are transferred from the next period to the current period. The auditor makes sure that no other techniques (methods) are used to conceal expenses or losses.

\section{Results:}

The linkages between theoretical constructs are empirically investigable using the structural equation modelling (SEM). SEM has the capacity to model and estimate the parameters for the relationships between theoretical constructs and test the theories of behavioural science (Bollen, 1989), and through its inclusion, an intuitive graphical representation of theory is possible. Using multiple observable variables, SEM differentiates between theoretical constructs and their empirical measurement (J. Henseler, 2017). J. Hair, Sarstedt, Hopkins, and Kuppelwieser (2014) further mentioned factor analysis, path analysis and regression as representatives of special cases of SEM. SEM can be regarded as the second generation of multivariate analyses (Fornell \& Bookstein, 1982).

Testing was done on the research model proposed using SEM. In particular, the technique of partial least squares (PLS), using the SMARTPLS software version 3.0 as proposed by Henseler, Ringle, and Sarstedt (2015), was applied. This technique follows variance analysis which comprises the simultaneous evaluation of the measurement model as well as the structural model (Roldán \& Sánchez-Franco, 2012). Since the indicators are manifestations of the construct, i.e., the construct determines the measure (Bagozzi, 2007), the direction of causality between the constructs and their indicators in this study, happens reflectively.

Due to three primary factors, this study finds the technique of PLS to be the most fitting. The first factor is this study's small sample size $(n=128)$, while PLS is appropriate for sample smaller than 250 (Reinartz, Haenlein, \& Henseler, 2009). Another factor is the focus of this study which is on the prediction of the dependent variable, which, according to Chin (2010), could benefit from the use of PLS. Further, some of the scales used have been validated in the literature (e.g., the dimension of sources of cognitive creativity) whereas other scales are not succinctly supported in literature and therefore, PLS should be chosen (Chin \& Newsted, 1999). Worded differently, in the context of this study, a comprehensively established theoretical framework is yet to exist.

As PLS has been chosen as the analyses tool, this study employed the SMART-PLS v. 3.2.7 software. PLS is a twostage approach instrument (Chin, 2010; Roldán \& Sanchez-Franco, 2012; Hair et al., 2014); it comprises two steps. In the first step, the measurement model is evaluated. Such evaluation enables the specification of the relationships between the observable variables and theoretical concepts. Meanwhile, evaluation is performed on the structural model in the second step. The purpose is to test the extent to which the causal relationships identified by the proposed model are consistent with the existing data.

\section{Measurement model:}

Tests were performed on the measurement model to determine the constructs' internal consistency reliability, convergent validity and discriminant validity. As articulated by Hair et al. (2014), Obeid, Salleh, and Mohd Nor (2017) and Al Shbail, Salleh, and Mohd Nor (2018a, 2018b), internal consistency reliability measures the degree to which the items are the latent constructs' measure. Composite reliability was evaluated as a measure of internal consistency (Hair et al., 2017). The model of measurement with composite reliability carrying higher value than the threshold value of 0.7 for each construct is regarded as satisfactory (Al-Shbiel et al., 2018; Richter et al., 2016). As can be seen from the results, the composite reliability for each constructs is higher than the cut-off value (0.7) - sources of cognitive creativity (0.902), type of cognitive creativity (0.884), enhancement of cognitive creativity (0.927) and reduce creative accounting practices (0.892) - denoting high internal consistency of the measures.

On the other hand, convergent validity evaluates the degree to which a measure has positive correlation with the alternative measures of the exact construct (Hair et al., 2017). Assessment of convergent validity is performed by checking the items' outer loading and the average variance extracted (AVE). In general, the value of the outer loadings should be at least 0.712, while an AVE score of 0.5 is deemed satisfactory (Avkiran, 2017). The internal consistency reliability and convergent validity outcomes can be referred in Table 1. 
Table 1. Measurement model

\begin{tabular}{|c|c|c|c|c|c|}
\hline Construct & Items & Loadings & $\begin{array}{l}\text { Cronbach } \\
\text { 's Alpha }{ }^{a}\end{array}$ & $\mathbf{C R}^{\mathrm{a}}$ & $\mathbf{A V E}^{\mathbf{c}}$ \\
\hline \multirow{8}{*}{ Sources of cognitive creativity } & SCC1 & 0.824 & \multirow{8}{*}{0.896} & \multirow{8}{*}{0.902} & \multirow{8}{*}{0.684} \\
\hline & $\mathrm{SCC2}$ & 0.776 & & & \\
\hline & SCC3 & 0.894 & & & \\
\hline & SCC4 & 0.813 & & & \\
\hline & SCC5 & 0.768 & & & \\
\hline & SCC6 & 0.912 & & & \\
\hline & SCC7 & 0.846 & & & \\
\hline & SCC8 & 0.835 & & & \\
\hline \multirow{7}{*}{ Type of cognitive creativity } & TCC1 & 0.768 & \multirow{7}{*}{0.889} & \multirow{7}{*}{0.884} & \multirow{7}{*}{0.649} \\
\hline & TCC2 & 0.902 & & & \\
\hline & TCC3 & 0.769 & & & \\
\hline & TCC4 & 0.912 & & & \\
\hline & TCC5 & 0.875 & & & \\
\hline & TCC6 & 0.793 & & & \\
\hline & TCC7 & 0.856 & & & \\
\hline \multirow{8}{*}{ Enhancement of cognitive creativity } & ECC1 & 0.934 & \multirow{8}{*}{0.911} & \multirow{8}{*}{0.927} & \multirow{8}{*}{0.739} \\
\hline & ECC2 & 0.798 & & & \\
\hline & ECC3 & 0.851 & & & \\
\hline & ECC4 & 0.936 & & & \\
\hline & ECC5 & 0.824 & & & \\
\hline & ECC6 & 0.859 & & & \\
\hline & ECC7 & 0.712 & & & \\
\hline & ECC8 & 0.877 & & & \\
\hline \multirow{8}{*}{$\begin{array}{l}\text { Reduce } \\
\text { practices }\end{array}$} & RCAP1 & 0.769 & \multirow{8}{*}{0.876} & \multirow{8}{*}{0.892} & \multirow{8}{*}{0.637} \\
\hline & RCAP2 & 0.822 & & & \\
\hline & RCAP3 & 0.902 & & & \\
\hline & RCAP4 & 0.834 & & & \\
\hline & RCAP5 & 0.871 & & & \\
\hline & RCAP6 & 0.750 & & & \\
\hline & RCAP7 & 0.819 & & & \\
\hline & RCAP8 & 0.767 & & & \\
\hline
\end{tabular}

\section{Structure Model}

The model fit is tested with the standardized root mean square residual (SRMR) as the discrepancy of root mean square between the correlations observed and the model-implied correlations (Hu \& Bentler, 1998). The SRMR for a composite factor model is determined as proposed by Henseler et al. (2016). This approach is used in order to determine the actual fit of the composite factor model. Therefore, it includes a confirmatory composite analysis. The model in the current study attains an SRMR for the composite factor model of 0.059 . Following the usual cut-off of 0.08 proposed by $\mathrm{Hu}$ and Bentler (1999), the obtained value demonstrates an appropriate fit.

The structural model assessment includes the analysis of the model's predictive competencies and of the linkages between the constructs. The evaluation of the structural model was performed according to: collinearity assessment, the algebraic sign, the magnitude and significance of the structural path coefficients, the values of $\mathrm{R}^{2}$ (variance explained), the $f^{2}$ effect size as well as the $\mathrm{Q}^{2}$ (cross-validated redundancy) test for predictive relevance (Roldán \& SanchezFranco, 2012).

In order to produce standard errors and t-statistics, bootstrapping was employed. This facilitates the evaluation of the statistical significance of the path coefficients. The outcomes show the significance of 3 out of the 3 conjectured relationships. In generating a 95\% confidence interval, the percentile bootstrapping produced identical result (Henseler et al., 2016). As mentioned by Castro and Roldán (2015), an interval with no zero value denotes its structural path coefficient being significantly different from zero, at $95 \%$ confidence level. As such, the path coefficient is deemed significant. The obtained outcomes are in support of Hypotheses 1, 2 and 3. 
As demonstrated, reduce creative accounting practices show considerable $\mathrm{R}^{2}$ values of 0.64 . As mentioned by Sarstedt, Ringle, and Hair (2014), $\mathrm{R}^{2}$ values support the in-sample predictive power of the model. With respect to the effect sizes $f^{2}$ for the structural model relationship, sources of cognitive creativity, type of cognitive creativity and enhancement of cognitive creativity each shows a medium and crucial effect size $(0.197,0.226$ and 0.245 respectively) on reduce creative accounting practices. Meanwhile, blindfolding was employed during the assessment of the model with the cross-validated redundancy index $\left(\mathrm{Q}^{2}\right)$ for the endogenous variables. This measure is appropriate for the examination of the predictive relevance of a theoretical/structural model (Chin, 2010). $\mathrm{Q}^{2}$ values higher than zero demonstrates the predictive relevance of the model (Tenenhaus, 1999). As evidenced by the outcomes presented in Table 2, for all the endogenous constructs, the structural model has satisfactory predictive relevance.

Table 2. Hypotheses verification

\begin{tabular}{|c|c|c|c|c|c|}
\hline \multirow[t]{2}{*}{ Structural path } & \multirow{2}{*}{$\begin{array}{c}\text { Path } \\
\text { coefficient } \\
\text { and (T } \\
\text { Statistics) }\end{array}$} & \multirow[t]{2}{*}{$\begin{array}{c}\text { Effect } \\
\text { size } \\
\left(f^{2}\right)\end{array}$} & $\begin{array}{c}\text { Percentile 95\% } \\
\text { confidence } \\
\text { intervals }\end{array}$ & \multirow[t]{2}{*}{$\begin{array}{c}\text { P- } \\
\text { Values } \\
(0.05 \%)\end{array}$} & \multirow[t]{2}{*}{ Conclusion } \\
\hline & & & $\begin{array}{cc} & 95 \% \\
95 \% \text { LL } & \text { UL }\end{array}$ & & \\
\hline H1: SCC -> RCAP & $0.187(3.288)$ & 0.197 & $(0.148 ; 0.369)$ & 0.000 & Supported \\
\hline H2: TCC -> RCAP & $0.213(3.347)$ & 0.226 & $(0.167 ; 0.432)$ & 0.000 & Supported \\
\hline H3: ECC -> RCAP & $0.194(2.943)$ & 0.245 & $(0.159 ; 0.398)$ & 0.001 & Supported \\
\hline
\end{tabular}

As shown in Table 2, hypothesis 01, 02, and 03 - that sources of cognitive creativity, type of cognitive creativity and enhancement of cognitive creativity have a positive effect on reduce creative accounting practices - are opposite postulated. The direct path from sources of cognitive creativity to reduce creative accounting practices is significant since the regression coefficient is 0.178 with $t$ value of $t=3.288$, and $p<0.05$. Therefore, we reject the null hypothesis and accept the alternative hypothesis. Also, the direct path from type of cognitive creativity to reduce creative accounting practices is significant since the regression coefficient is 0.213 with $t$ value of $t=3.347$ and $p<0.05$. The third hypothesis it is also not accepted because the direct path from enhancement of cognitive creativity to reduce creative accounting practices is significant since the regression coefficient is 0.194 with $t$ value of $t=2.943$ and $p<$ 0.05. Thus, we reject the null hypothesis and accept the alternative hypothesis.

\section{Conclusion}

This study examines the impact of cognitive creativity in the accounting with its three dimensions (creativity type, creativity source, and creativity reinforcement) among Jordanian internal auditors on detecting creative accounting practices in the Jordanian public joint stock companies. The results of the study indicate that there is a significant positive impact of cognitive creativity in the accounting field among Jordanian internal auditors in detecting creative accounting practices in order to make the financial statements of companies appear accurate and fairly for all users of financial statements, especially investors .Based on the findings, the researcher recommends the following: Enhancing the role of the supervisory bodies, especially the internal audit function in the sample companies, since internal audit is considered as a basic pillar and the most important component of internal control therein, as well as the need to develop the regulations and legislations that regulate the work of the internal auditor, so that he can perform the audit of all elements and components of the financial statements professionally away from management pressures so that he can detect all creative accounting practices. The study also recommends activating the role of the audit committees and giving them greater powers to detect any misinformation in the financial statements to mitigate the use of creative accounting, as well as giving auditors more attention through organizing annual courses and workshops and updating them on the expertise of external auditors as regards the new methods for detecting creative accounting. The study also recommends conducting more scientific studies in the field to know the effect of cognitive creativity in the field of accounting among Jordanian internal auditors to reduce the level of creative accounting. Of the creative accounting practices on the sectors other than those covered by this study to find out the extent of agreement or disagreement with the results of the current study whilst taking consideration of other variables.

\section{References}

Abdul Fattah, Mohamed, (2011), Proposed Framework for Realizing the Objectiveness of the Auditor's Report in Light of Profit Management - A Field Study, Master Thesis, Faculty of Commerce, Ain Shams University, Egypt. 
Abu Ajilah, Emad Mohammad and Hamdan, Allam (2009), The Impact of Corporate Governance on Profit Management (A Guide from Jordan)", presented to the Scientific Forum on the Financial and Economic Crisis, Farhan Abbas University, Setif, Algeria.

Abu Tamam, Maysaa Mohammad, (2013), The Extent to Which Accountants, Auditors, Financial Analysts and Users of Financial Statements Understand Accounting Practices on the Cash Flow Statement, Master Thesis, Middle East University, Jordan.

Al-Agha, Emad Saleem (2011) The Impact of Corporate Governance on Reducing the Negative Impact of Creative Accounting on the Reliability of Financial Data, Al-Azhar University, Gaza, Master Thesis.

Al-Ameen, Maher and Al-Omari, Ahmad and Abdel Halim, Maryam (2014), Evaluation of the Procedures for Detecting Creative Accounting Methods Applied at Syrian Shareholding Companies by the External Auditor: A Field Study. Tishreen University Journal for Research and Scientific Studies - Series of Economic and Legal Sciences, 36 (1).

Al-Ameen, Maher Ayyash (2015), The role of the External Auditor in Measuring the Relationship between the Methods and Motives of Creative Accounting in Syrian Shareholding Companies - Field Study, Tishreen University Journal, Aleppo, Syria, Volume 37, Issue No. 6.

Al-Fadhl, Moayad (2009), Creativity in Administrative Decision-Making, 1st Edition, Dar Ethraa for Publishing and Distribution, Amman, Jordan.

Al-Ghadnafari, Muhammad Zafer Abdul-Khaliq (2013), Contributions of Ethical Accounting Behavior in Limiting Creative Accounting Practices, A Survey Study at the Faculty of Management and Economics, Mosul University, Rafidain Development Journal, Issue 114, Vol 35.

Al-Hadi, Adam Mohammad and AlHussein, Majeed and Al-Baaj, Qassim (2017), The Effect of Creative Accounting on the Quality of Creative Accounting, Journal of Administrative Sciences, International University of Africa, Faculty of Administrative Sciences, Issue No.1.

Al-Halabi, Linda Hassan Nimer (2009), The Role of the External Auditor in Limiting Creative Accounting Practices on the Reliability of Financial Statements Issued by Jordanian Public Shareholding Companies, Master Thesis, Middle East University, Jordan.

Al-Jaarat, Khalid, and Abu-Khalifa, Dina (2015), Creative Accountability and Reliability: A Proposed Model for the Controls of Creative Accounting Practices, Algerian Journal of Accounting and Financial Studies, Algeria, Issue 1.

Al-Khashawi, Ali Mahmoud, Al-Dosari, Mohsen Nasser (2008) "Creative Accounting and the role of the auditor in verifying its practices and results", scientific research presented to the Kuwait Audit Bureau, Kuwait.

Al-Kilani, Basma Qays (2008), The Effect of Creative Accounting on Financial Statements and the Role of the Auditor in Reducing Them - An Empirical Study on a Number of Companies in the Mixed Sector, Research Presented to the Higher Institute of Accounting and Financial Studies - University of Baghdad, Iraq, 2008.

Alnsour, Mahmoud (2009), The Effect of Management Incentives and Characteristics of Audit Committees on the Effectiveness of Internal Auditing in Jordanian Industrial Public Shareholding Companies, unpublished $\mathrm{PhD}$ Thesis, Arab Academy for Financial and Financial Sciences, Amman, Jordan.

Al-Obaidi, Sabeeha, (2008), The Role of Institutional Control in Reducing Creative Accounting Practices and Achieving Compatibility between the Interests of the Agency's Parties, unpublished PhD thesis, Faculty of Management and Economics, Baghdad University, Iraq.

Al-Oday, Ibrahim and Sqour, Rana (2014), The Impact of an Effective Internal Control System on the Limitation of Profit Management Practices", Tishreen University Journal of Research and Scientific Studies, Aleppo, Syria, Volume 36, Issue 3.

AlQutaish, Hassan Falih, and Al-Sofi, Fares Jameel (2011), Creative Accounting Methods in the Income Statement and Balance Sheet of the Industrial Public Shareholding Companies Listed in the Amman Stock Exchange, Baghdad Journal of Economics, Baghdad, Issue No. 27.

Al-Zayadi, Naeem Toman (2015), The Effect of Creative Accounting Methods on the Reliability of Financial Statements - An Empirical Study, Al Qadisiya Journal of Administrative and Economic Sciences, Al Qadisiyah University, Iraq, Volume 17, Issue 2.

Ammoura, Jamal and Sharifi, Ahmad (2011), (2011), Creativity and Organizational Change in Modern Organizations: Study and Analysis of National and International Experiences, scientific research presented at the First International Conference held at the Faculty of Economics and Management Sciences, University of Blida, Algeria, 18-19 May 2011.

Bataineh, Louay Badie (2010), Creative Accounting in Financial Statements. www.main.omandaily.com 
Dahmash, Naeem and Abu Zir, Afaf (2005) Creative Accounting Ethics, Presentation and Analysis, research presented to the First Scientific Conference at the Faculty of Administrative and Financial Sciences, Al Isra University, Jordan.

Hussein Ali Ibrahim (2010), The Effect of Creative Accounting on Investor Decisions in the Shadow of Variable Market Efficiency: A Case Study on a Sample of Investors at the Iraqi Stock Market, Future Research Journal, University of Mosul, Iraq, Issue No. 31, 32.

Ismail, Mejbel Dawi (2014), The Effect of Creative Accounting Techniques on the Reliability of Accounting Information, Applied Research in a Government Bank, Qadisiyah Journal of Administrative and Economic Sciences, Vol 16, Issue No.3, Iraq.

Khalawi, Sattar Jabbar and Kazim, Enass (2016), The Fair Value and Effect of Its Usage in Creative Accounting Applications - An Empirical Study of the Middle East Commercial Bank and Al-Mansour Bank, Al-Kout Journal of Economic and Administrative Sciences, Faculty of Economics, Wasit University, Iraq, Issue No. 24.

Laarousi, Asia and Qassimi, AlSaeed (2016), Measuring Creative Accounting Practices in the Algerian Environment Using Optional Accruals - Case Study of Some Enterprises Listed on the Algiers Stock Exchange, Journal of Human Sciences, University of Messila, Algeria, Issue No. 6, December.

Majeed, Batool Mohammad (2013), The Auditor's Challenge of Creative Accounting Practices, Journal of Administration and Economics, Mustansiriya University, Iraq, 36th Year, Issue No. 96.

Meshhen, Abdullah (2015), The Use of Creative Accounting Methods and Procedures in Financial Statements", An Applied Study of a Sample of Iraqi Banks, Tikrit Journal of Administrative and Economic Sciences, Volume 11, Issue No. 33, Iraq.

Mohmed, Mahmoud Ramadan (2005), Accounting Creativity, Forum on the Roles of Accountants and Auditors in Management Decisions and Resource Development, Arab Organization for Administrative Development (ARADO), Arab League, Egypt.

Mokalled, Mohamed Mohsen (2010), The Positive Theory of Accounting and Its Explanations of the Management's Motives for Accounting Option Alternatives, PhD Thesis, Faculty of Commerce, Alexandria University, Egypt.

Ramo, Waheed Mahmood (2008), Conceptual Framework for Creative Accounting under the Rules and Ethics of the Accounting Profession and International Accounting and Auditing Standards, Rafidain Development Journal, Mosul University, Iraq, Volume 89, Issue 30.

Zabayneh, Saeed Abdel-Qader (2008), The Impact of Compliance with Generally Accepted Internal Auditing Standards and the requirements of the Sarbanes-Oxley Act (404) on the Effectiveness of Internal Audit in Public Shareholding Companies Listed in the Palestinian Financial Market, unpublished PhD thesis, Arab Academy of Financial and Banking Sciences, Amman, Jordan. 